\title{
Basal cell carcinoma of the conjunctiva
}

\author{
MOHAMMED AFTAB AND S. P. B. PERGIVAL \\ Department of Ophthalmology, Scarborough Hospital, Scarborough, Yorks
}

The purpose of this communication is to report a rare pathological finding in a lesion which appeared clinically to be an entirely innocent conjunctival papilloma.

\section{Case report}

An 82-year-old man attended on June 14, 1972, with a pedunculated lesion of the conjunctiva approximately $4 \mathrm{~mm}$. in diameter. It was situated nasally in the palpebral aperture between the limbus and the plica. He gave a vague history of its duration, although in recent months he had noticed that it had increased in size. The lesion was fleshy and mobile and had no vascular core. It was excised under a local anaesthetic the same morning, and when the patient was seen 2 months later there was no sign of recurrence. The following October, however, the patient was found in a different department to be suffering from myelomatosis; he died shortly afterwards without further ophthalmic examination.

OGULAR PATHOLOGY

Histologically this was a basal cell carcinoma. The lesion was composed of tumour cells surrounding islands of connective tissue (Fig. I).

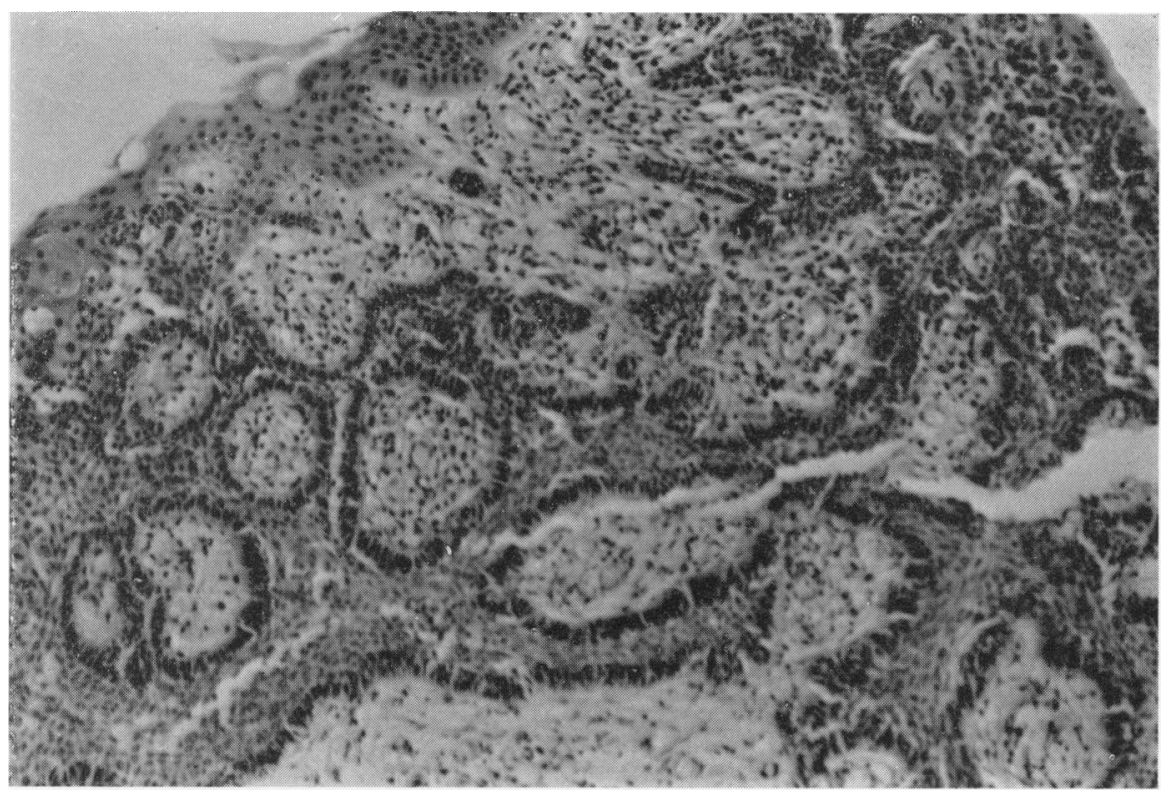

FIG. I Section of tumour, showing interlacing strands of basal cells surrounding islands of connective tissue Haematoxylin and eosin. $\times 100$

The basal cells of the epithelium of the conjunctiva were continuous with the palisaded cells surrounding the tumour tissue (Fig. 2). Elsewhere there were sheets of tumour cells showing a whorled pattern, suggesting early squamoid differentiation. 


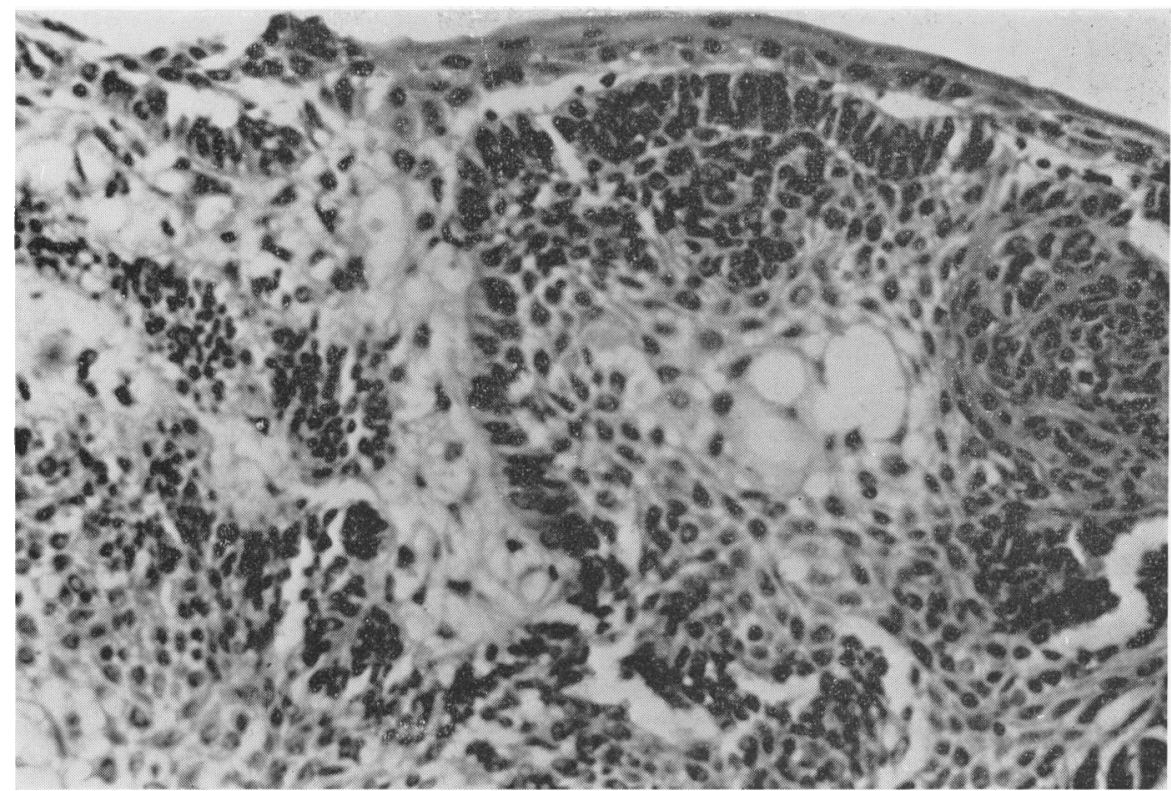

FIG. 2 Carcinoma cells arising from basal layer of conjunctival epithelium. Haematoxylin and eosin $. \quad \times 250$

\section{Comment}

Carcinoma of the conjunctiva is uncommon. It may arise from pre-existing leukoplakia, intraepithelial epithelioma (Bowen's disease), papilloma, or spontaneously after metaplasia of an area of conjunctival epithelium (Reese, I 963). Commonly there is initial dyskeratotic change in the epithelium and this may be present microscopically in an area surrounding the macroscopic lesion. The lesion itself tends to be flat and spreading, and may invade the cornea or sclera.

Basal cell carcinoma of the conjunctiva is extremely rare; the report of Ash and Wilder ( 1942), based on 93 cases of epithelial tumours of the limbus, described 28 papillomas, I 7 dyskeratotic lesions, 47 squamous cell or papillary squamous cell type carcinomas, but only one basal cell carcinoma.

The lesion reported here is of interest in that it was of the basal cell type of carcinoma, and in that this was pedunculated rather than flat, suggesting that it had possibly developed in a pre-existing papilloma. The site of the carcinoma (within the palpebral aperture and near the limbus) and the age and sex of the patient are typical of the condition and agree well with the findings of Ash and Wilder (1942) and Ash (1950).

\section{Summary}

A report of basal cell carcinoma of the conjunctiva is recorded with an unusual clinical appearance.

We are grateful to Dr. J. P. S. Whitehead for kindly providing the pathological report.

\section{References}

AsH, J. E. (1950) Amer. J. Ophthal., 33, I 203 and WILDER, H. c. C. (I942) Ibid., 25, 926

REeSE, A. B. (I963) "Tumors of the Eye", 2nd ed., pp. 23-26. Harper and Row, New York, Evanston, and London

D 